\title{
Ota Horák
}

\section{Epiktétos: kognitívny terapeut}

\section{Epiktétos - filozof a terapeut:}

Myšlienkové dielo stoika Epiktéta je nielen svojbytným prejavom filozofického myslenia, ale zároveň i ucelenou psychoterapeutickou koncepciou. Epiktétov filozofický počin prekračuje rámec teoretickej výpovede do oblasti filozofickej praxe určitého spôsobu života s ciel'om navodit' konštruktívnu zmenu osobnosti. Jeho filozofia je výcvikom v umeni žit', ktorý lieči. Epiktétos je filozof i psychoterapeut zároveň.

Epiktétovo filozofické dielo je plnohodnotným psychoterapeutickým systémom, pretože obsahuje všetky jeho podstatné zložky: 1. teóriu osobnosti - človek ako racionálna bytost', ktorá vo svojej duši neobsahuje žiadne stopy iracionality, 2. psychopatológiu - zoznam deštruktívnych emócií a ich patologických účinkov na človeka, 3. spôsob terapie - alebo spôsob liečby, ktorý spočíva $\mathrm{v}$ zasadení pacientovho uvažovania do perspektívy božskej, kozmickej dimenzie. ${ }^{i}$ Jej prostredníctvom sa pacient zbavuje deštruktívnych emócií a nastupuje cestu smerom $\mathrm{k}$ ušl'achtilému človeku, ktorý pokoj, kl’ud a mier nachádza ako prirodzené stavy duše ${ }^{i i}$. Absolvovanie kompletného terapeutického

\footnotetext{
i „[...] poznaj sám seba, [...] bez boha sa o to nepokúšaj.“ Diss. III, 22, s. 254.

${ }^{i i}$ Epiktétos sa nepridržiaval zavedenej stoickej klasifikácie na štyri negatívne a tri pozitívne emocionálne stavy. V súvislosti s deštruktívnymi emóciami hovoril napr. o žiali, strachu, zármutku, závisti, škodoradosti, hrabivosti, zmäkčilosti, nezdržanlivosti, nespokojnosti, popudlivosti, zbabelosti, chvastaniu, nekl'ude apod. K tomu vid' Diss. II, 16, s. 168 a Diss. III, 2, s. 211.
} 
tréningu vedie u človeka k odstráneniu trýznivého stavu, v ktorom sa pôvodne nachádzal a k jeho nahradeniu stavom konštruktívnym, ktorý je Epiktétovi výrazom pre l'udské zdravie, blaženost' a osobnostný rast. ${ }^{i}$

\section{Teória osobnosti ako východisko terapeutických úvah:}

Všetky činnosti, pri ktorých človek užíva svoj rozum, má vo svojej moci, inak povedané, všetko, čo je späté s rozumom, nepodlieha žiadnym vonkajším obmedzeniam, ale je celkom na nás.ii Epiktétos nevkladá do duše žiadne iracionálne zložky iii a pretože svet nikdy nezakúšame bez

Čo sa týka konštruktívnych (pozitívnych) emócií, mal pod nimi na mysli trpezlivost', ušl'achtilost', statočnost', znášanlivost', vlúdnost', láskavost', zhovievavost', priatel'stvo, slobodu apod. K tomu vid' napr. Diss. II, 16, s. 165 a Diss. II, 22, s. 192.

i Epiktétos napíña vymedzenie a ciele psychoterapie ako ich definuje Kratochvíl: „Psychoterapia je pôsobením, ktoré má odstránit' alebo zmiernit' problémy a podl'a možnosti i odstránit' ich prićiny. Má [...] viest' $\mathrm{k}$ obnoveniu zdravia, k poznaniu a obmedzeniu sebazničujúceho chovania, $\mathrm{k}$ účinnému zvládaniu problémov, konfliktov a životných úloh. Má pomáhat' pacientom zmenit' prežívanie $\mathrm{v}$ smere lepšieho prispôsobenia životným úlohám a situáciám alebo v smere, ktorý sami považujú za žiaduci a na ktorom sa dohodnú $\mathrm{s}$ terapeutom. Má viest' $\mathrm{k}$ pocitom sebauplatnenia a sebarealizácie vlastných možností a k naplňovaniu životného zmyslu, k pocitu vyrovnanosti a spokojnosti.“ Kratochvíl 2002, s. 13.

ii „Niektoré veci sú v našej moci, iné nie sú v našej moci. V našej moci je súd, chcenie, žiadost', nechut' a jedným slovom všetko, čo je naša činnost'; v našej moci nie je telo, majetok, dobrá alebo zlá povest', úradné hodnosti, jedným slovom všetko, čo nie je naša činnost'. A čo je v našej moci, je od prírody slobodné, nepodlieha prekážkam, ani závadám; čo však nie je v našej moci, je slabé, otrocké, podlieha prekážkam a je cudzie. Maj teda na pamäti, že ak budeš pokladat’ to, čo je od prírody otrocké, za slobodné, a to, čo je cudzie, za svoje vlastné, budeš narážat' na prekážky, budeš trúchlit', budeš sa znepokojovat' a reptat' na bohov aj na l'udí; ak však budeš len to, čo je tvoje, pokladat' za svoje, a cudzie, ako po pravde jest, za cudzie, potom t'a nikdy nikto nebude môct' nútit', nikto ti nebude môct' bránit', na nikoho nebudeš reptat', nikomu nebudeš nič vyčítat', naprosto nič nebudeš robit' proti svojej vôli, nebudeš mat' nepriatel'ov, nikto ti nebude škodit', lebo žiadnu škodu nebudeš môct' trpiet'.“ Ench. I, s. 27.

iii Epiktétos nevkladá do duše človeka žiadne iracionálne (vznetlivost', žiadostivost',...) zložky. V koncepciách, kde iracionálne emócie naopak vystupujú ako súčast' l'udskej prirodzenosti, neusiluje ich nositel' o to zbavit' sa ich, pretože mu ide o nastolenie správneho harmonického vzt’ahu medzi nimi. Tak to nachádzame napr. u Platóna alebo v strednej stoy 
sprostredkovania našich súdov ${ }^{\mathrm{i}}$ - ktoré sú plne v našej moci - sú všetky deštruktívne emócie, medzi nimi napr. strach a smútok, dôsledkom chybného súdenia, zlého zaobchádzania $\mathrm{s}$ rozumom. Možno preto konštatovat', že Epiktétovi je správne užívanie predstáv výrazom pre emocionálne, duševné zdravie.ii Kto myslí dobre, je duševne zdravý.

Pacienta nikdy neznepokojuje vec samotná, ale len jeho predstava o nej. Každá deštruktívna emócia tak nie je výsledkom pôsobenia objektívne zlého stavu vecí, ale púhej predstavy, ktorá ony deštruktívne emocionálne stavy vyvoláva. iii V̌̌etky predstavy však môžu podliehat' vedomej kontrole a následne odmietnutiu. Metódu, ktorú za tým účelom Epiktétos volí, možno pomenovat' ako metódu „bdelého uvedomovania si“ predstáv: „Zvykaj si teda pri každej znekl'udňujúcej predstave ihned' dodávat': ,Si len predstava a naprosto nie to, čím sa zdáš byt'.“ A potom skúšaj a skúmaj podla tých pravidiel, ktoré si si osvojil, ale predovšetkým podl'a toho prvého: či sa predstava vzt’ahuje k veciam, ktoré sú v našej

u Poseidónia a Panaitia. K tomu vid’: Sorabji 1999, s. 802-3. U Epiktéta však všetko, čo nie je rozumové, je ako iracionálne zároveň protiprirodzené, a preto deštruktívne. Epiktétos navrhuje, aby sme sa všetkých deštruktívnych emócií zbavili.

i „L’udia nie sú znepokojení vecami, ale svojimi vlastnými názormi o veciach. [...] Kedykol'vek teda narážame na prekážky alebo sa znepokojujeme, alebo sa rmútime, nikdy neobviňujme iného, ale seba samých, to jest svoje vlastné názory.“ Ench. 5, s. 29, „Maj na pamäti, že t’a urazí nie ten, kto ti nadáva alebo t’a bije, ale tvoja mienka, že t’a títo l'udia urážajú. Kedykol'vek t’a teda niekto rozčúli, vedz, že t’a rozčúlila len tvoja domnienka.“ Ench. 20, s. 33, Vid' tiež Ench. 1, s. 27-8.

ii „Jedny z vecí vložil boh do našej moci a iné nevložil. Do našej moci vložil to najkrajšie a najdôležitejšie, [...] schopnost' užívat' predstáv. Lebo ak ich správne užívame, znamená to slobodu, št’astný život, dobrú mysel', nekolísavost'; znamená to aj spravodlivost', zákon, umiernenost' a vôbec každú cnost'.“ Fr. 4, s. 360, „Ciel'om človeka je nasledovat' bohov a podstatou dobra je náležité užívanie predstáv.“ Diss. I, 20, s. 100

iii „L’udia nie sú znepokojení vecami, ale svojimi vlastnými názormi o veciach.“ Ench. 5, s. 29, „Maj na pamäti, že t’a urazí nie ten, kto ti nadáva alebo t’a bije, ale tvoja mienka, že t’a títo l'udia urážajú. Kedykol'vek t’a teda niekto rozčúli, vedz, že t’a rozčúlila len tvoja domnienka.“ Ench. 20, s. 33, „Zvykaj si teda pri každej znekl'udňujúcej predstave ihned' dodávat': ,Si len predstava a naprosto nie to, čím sa zdáš byt'.“' Ench. 1, s. 27-8. 
moci, či k veciam, ktoré nie sú v našej moci; a ak sa vzt'ahuje k niektorej z vecí, ktoré nie sú v našej moci, ihned’ si uvedom: ,Netýka sa ma. “‘i

Osvojenie si Epiktétom navrhovanej teórie osobnosti, ktorá je plne rozumová takže neobsahuje žiadne iracionálne (= deštruktívne) zložky, ktoré by sme v súlade $\mathrm{s}$ dobovou filozofickou tradíciou mohli pomenovat' napr. ako žiadostivost', vznetlivost' apod. je východiskom terapeutického procesu. Vytrvalým tréningom ${ }^{\mathrm{ii}}$ sa pacient učí neustálej bdelosti, pozornosti, aby mal permanentne na pamäti slobodu svojho rozumu, ktorý nepodlieha žiadnym obmedzeniam či prekážkam ako zdrojom deštruktívnych emócií.

\section{Terapia božskou perspektívou:}

V tomto - bohom preniknuvšom - svete disponuje l'udská bytost' naprosto jedinečným postavením iii vd'aka svojej unikátnej mohutnosti rozumu. Iným menom pre boha je Epiktétovi rozum, boh je rozum a človek je rozumová bytost'. ${ }^{\text {iv }}$ Boh ako rozum a človek ako rozumová bytost ${ }^{\text {i }}$ sú

\footnotetext{
${ }^{\mathrm{i}}$ Ench. 1, s. 27-8.

Vid' tiež: „Ak uvol'níš čo i len nakrátko svoju pozornost', nepredstavuj si, že ju zase privoláš, kedykolvek sa ti bude chciet', ale to si dobre uvedom, že svojím dnešným pochybením nevyhnutne budeš menej spôsobilý ku všetkým ostatným úkonom. Lebo predovšetkým tým vzniká, a to je zo všetkého najhoršie, zvyk nedávat' pozor a potom zvyk odkladat' pozornost'; a tak sa ti stane zvyklost'ou stále na inú a inú dobu odkladat' št'astný a slušný život, chovanie zhodné s prírodou a zotrvávanie v ňom. [...] prečo nezachovávaš pozornost' ustavične?“' Diss. IV, 12, s. 351, vid’ tiež Diss. III, 10, s. 227.

ii „Nie je totiž možné bez vel'kého a vytrvalého cvičenia zaistit' našu žiadost', aby sa neklamala a našu nechut', aby neupadala do toho, čomu sa chce vyhnút'، Diss. III, 12, s. 231.

iii „Lebo ak by bol boh učinil tú čiastku, ktorú sám od seba oddelil a nám dal, takú, že by podliehala zabraňovaniu a prinucovaniu zo strany jeho samotného alebo kohokol'vek iného, nebol by to už boh a nestaral by sa o nás tak, ako by mal.” Diss. I, 17, s. 93.

iv „Čo teda je božia podstata? Mäso? Uchovaj bože! Pozemok? Uchovaj bože! Povest'! Uchovaj bože! Rozum, vedenie, správne myslenie. Len tu teda a len tu hl'adaj pravú podstatu dobra! [...] Ty však si vedúcou bytost’ou, ty si diel boha a máš v sebe akúsi jeho
} 
k sebe bezprostredne vztiahnutí. Prirodzenost' l'udská a prirodzenost' božská sú zviazané rozumom. Ak teda podstupujeme Epiktétom navrhovanú terapeutickú liečbu a kultivujeme našu mysel' tým, že ju uvádzame do súladu s našou prirodzenost'ou ako rozumom nadanou bytost'ou, identifikujeme všetko, čo sa deje mimo našej moci, ako prejav boha." Smrt', neúroda na poli, hlad, bolest',... (oblast' vecí vonkajších, ktoré - na rozdiel od vnútornej, rozumom založenej slobody - človek vo svojej moci nemá a nedokáže ich ovplyvnit') - to všetko patrí ku svetu; $\mathrm{v}$ bohom preniknuvšom svete a $\mathrm{z}$ božskej perspektívy však vymenované javy nepredstavujú žiadnu hrozbu, nad ktorou by sa mal človek rmútit', ved' nie je možné, aby boh človeka odvrhol a nechal napospas deštruktívnym stavom, s ktorými sa rozum, boží dar človeku, vylučuje. Epiktétos píše: „Nuž, nedostalo sa vám schopností, ktorými vyzbrojení znesiete každú príhodu? [...] ,Áno, ale trápi ma nádcha!' $\mathrm{K}$ čomu teda máš ruky, človeče? Či nie tiež k tomu, aby si si osušil nos? ,Je teda rozumné, že je vo svete nádcha?‘ A o čo je lepšie osušit’ si nos ako nariekat? [...] Nuž teda tiež ty si toto uvedom a maj na pamäti schopnosti, ktoré máš a nepúštajúc ich z

čast' [...] Boha všade v sebe nosís.““ Diss. II, 8, s. 141-2. Podobne sa Epiktétos vyjadruje v Diss. I, 9, s. 73, Ench. I, 14, s. 87 a na mnohých iných miestach.

${ }^{\mathrm{i}}$ Epiktétos je jediným stoikom, ktorý učinil z prohairesis klúčový termín. Skorší stoici odkazovali na racionalitu skrze štandardný termín pre l'udskú mysel', hégemonikon, ktorý doslova znamená riadiaci princíp. Epiktétos sa k racionalite hlási skrze termín prohairesis, ktorý vyhradzuje jedine l'ud'om a bohu. Prohairesis odkazuje na l'udskú mysel' v tých schopnostiach a dispozíciách, ktoré Epiktétos prehlasuje, že sú na nás a nepodliehajú vonkajším obmedzeniam, na rozdiel od vonkajšich vecí. K tomu viac v Long 2004, s. 28-29, 211-214, 217-8.

ii „Prečo chcem, čo nesmiem chciet', prečo chcem mat' stoj čo stoj, čo mi nie je dané. Ale ako mám chciet' veci? Ako sú dané [...]“ Diss. IV, 1, s. 300, „[...] vždy chcem radšej to, čo sa práve deje. Lebo za lepšie pokladám to, čo chce boh, ako to, čo chcem ja. K nemu sa chcem pripojit' ako služobník a sprievodca: jeho chcenie je moje chcenie, jeho žiadost' je moja žiadost', slovom jeho vôla je moja vôlaa“" Diss. IV, 7, s. 330-2 a nakoniec ,[...] všetko, čo sa deje v zhode s prírodou, správne sa deje.“ Diss. I, 11, s. 78. 
mysli, hovor si: ,Zošli mi teraz, bože, ktorúkol'vek tieseň chceš; lebo mám výzbroj od teba mi danú a prostriedky k tomu, aby mi všetky príhody boli ozdobou. "،i

Človek má vo svojej moci jedine užívanie vlastných predstáv, a to také, že môže byt' bud' $\mathrm{v}$ zhode alebo $\mathrm{v}$ rozpore $\mathrm{s}$ jeho prirodzenost'ou rozumovej bytosti. Kultiváciou rozumu sa človek pripodobňuje bohu, objavuje veci z božskej perspektívy, takže všetko, čo ho stíha, identifikuje ako prirodzené, a teda konštruktívne. Pre rozumom kultivovaného človeka, ktorý sa posadil do spoločnosti boha, vzchádza prospech z každej situácie. ${ }^{\text {ii }} \mathrm{V}$ nešt’astie a nepokoj tak upadá jedine ten, kto nevie, že je práve v moci jeho rozumu, aby mu každá situácia bola ozdobou.iii Každý, kto sa rmúti nad smrtou svojho priatel'a, rmúti sa nad vecou vonkajšou, tým, čo nemá vo svojej moci, ale čo mu je uložené. Nerozumnou je snaha človeka menit' veci, na ktoré nemá ani nemôže mat' žiaden vplyv. Nemožnost' menit' a ovplyvňovat' vonkajšie veci však neústi do zúfalstva a úzkosti, pretože rozumové spojenectvo $\mathrm{s}$ bohom človeku diktuje vzhliadat' ku každej vonkajšej udalosti ako božskej, rozumnej, prirodzenej, a teda konštruktívnej.

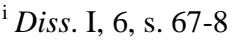

ii „Ale ak pozoruješ seba ako človeka a ako čast' nejakého celku, potom práve pre tento celok je ti primerané raz stonat', potom sa zase plavit' morom a podstúpit' nebezpečenstvá a potom byt' v núdzi či hocikedy i predčasne zomriet'. Prečo sa teda mrzíš? Nevieš, že ako noha, ak sa odlúči, už nebude nohou, tak ani ty, ak sa odlúčiš, už nebudeš stále človekom?“ Diss. II, 5, s. 136, „Teraz je vhodná chvíl'a mat' horúčku: nech sa to deje správne; teraz je čas byt' o smäde; znášaj smäd správne; teraz je čas hladovat'; znášaj hlad správne! Či to nie je v tvojej moci? Kto ti v tom zabráni? Pit' ti zabráni tvoj lekár, ale správne byt' smädný ti nemôže zabránit'; [...]“ Diss. III, 10, s. 228.

iii ,[...] nikto nie je nešt’astný vinou iného.“ Diss. I, 9, s. 76.
} 


\section{Samovražda a smrt':}

Pacient, ktorý hl'adí na svet z božskej perspektívy, je k riešeniu životných problémov, ktoré ho stretnú, pozitívne naladený. Nič nie je natol'ko deštruktívne, aby sa tým človek nemohol ozdobit'. Epiktétov pacient hladí sebavedome pred seba a všetkému čelí ako výzve, ktorá len čaká na svoje prekonanie. Prekážky ho potom nedeštruujú, ale naopak posilňujú a zdokonal'ujú. Bolo by snád' Olympijského vít'aza bez toho, že by čelil najtvrdším úderom a súperom $\mathrm{v}$ tréningu?, pýta sa Epiktétos.i Napriek tomu môžu nastat' situácie, kedy je úder natol'ko silný, že pacient tlaku podl'ahne a ako východisko zo situácie si zvolí samovraždu. Epiktétos nám však nedovol'uje interpretovat' ju ako výraz sebadeštrukcie, rezignácie, paralýzy či l’ubovôle pacienta. Naopak, v rámci Epiktétovej myšlienkovej schémy sa javí ako perfektne racionálna. Človek, ktorý sa svojím rozumom uviedol do súladu s bohom, pokial' od neho dostane signál pre to, aby spáchal samovraždu, protivil by sa mu, ak by jeho výzvy neupočúvnul. Ak sa hostina na boží povel skončila, človek sa musí rozlúčit' a odíst'. Všetko, čo vzchádza od boha, je správne bez ohl'adu na to, čo to je - impulz k samovražde nevynímajúc.ii

\footnotetext{
i „Potiaže sú to, čo ukazuje muža. Kedykol'vek t’a nabudúce stretne problém, spomeň si na to, že boh ako nejaký učitel' zápasníctva t’a určil k zápasu s urputným mládencom. ,A prečo?` opýta sa niekto. Preto, aby si sa stal vít’azom v olympijských hrách, ale to bez potu nie ide.“ Diss. I. 24, s. 105. „Nuž, nedostalo sa vám schopností, ktorými vyzbrojení znesiete každú príhodu? [...], Áno, ale trápi ma nádcha!' K čomu teda máš ruky, človeče? Či nie tiež k tomu, aby si si osušil nos? ,Je teda rozumné, že je vo svete nádcha?`A o čo je lepšie osušit' si nos ako nariekat'? [...] Nuž teda tiež ty si toto uvedom a maj na pamäti schopnosti, ktoré máš a nepúšt'ajúc ich z mysli, hovor si: ,Zošli mi teraz, bože, ktorúkol’vek tieseň chceš; lebo mám výzbroj od teba mi danú a prostriedky k tomu, aby mi všetky príhody boli ozdobou. “" Diss. I, 6, s. 67-8.

ii „,,Ale čo ked' mi [boh] neposkytne obživu?‘ A čo iné to je, než že ako dobrý velitel' mi dal znamenie $\mathrm{k}$ ústupu? Počúvam, podrobujem sa a pritom velebím svojho velitela a blahoslavím jeho činy. Lebo som sem prišiel, ked' on chcel; opät' odídem, ked' sa jemu bude chciet', [...]“ Diss. III, 23, s. 285-6.
} 
Život však človek nekončí len z vlastného rozhodnutia. Na základe toho, čo o Epiktétovej terapii už vieme, bude zrejmé, ako Epiktétos obavy zo smrti neutralizuje. Smrt' je vec vonkajšia, o jej dátume nerozhodujeme, čo však ovplyvnit' môžeme, je, akú predstavu si o nej vytvoríme. Pacient, ktorý rozoznal svoje unikátne - rozumom založené - spoločenstvo s bohom, sa nermúti nad tým, čo je prirodzené.i Človek, ktorý podstúpi Epiktétom navrhovanú liečbu, neupadá do deštruktívnych stavov smútku a nepokoja, pretože z božskej perspektívy je smrt' udalost'ou rozumnou, prirodzenou, a teda konštruktívnou.

\section{Epiktétos ako predchodca modernej kognitívnej terapie:}

Epiktétos nehl'adá príčiny pacientových problémov $\mathrm{v}$ jeho sexuálnom pude, traume prežitej $\mathrm{v}$ detstve či nevhodných vzorcoch jednania naučených z jeho okolia - ako to činia iné psychoterapeutické systémy - ale v nesprávnom myslení. Všetkým deštruktívnym emóciám Epiktétos rozumie ako výsledku zlého zaobchádzania s rozumom, preto psycho-patológia, kedy je človek stravovaný deštruktívnymi emóciami, vzniká ako dôsledok chybného súdenia. Je však v moci pacienta odhalit' potenciál svojho rozumu, ktorý nepodlieha žiadnym obmedzeniam, aby pri pohl'ade na veci z božskej perspektívy vo svojom nositel'ovi generoval

i „Prečo sa napríklad rodia klasy? Či nie je preto, aby tiež uschli? Ale neusychajú preto, aby aby boli tiež požaté? Lebo sa nerodia odlúčené od celku. Keby teda mali cítenie, mali by si priat', aby vôbec nikdy neboli požaté? Ale to by bola kliatba, keby neboli nikdy požaté. Práve tak vedzte, že aj pre ludí by bolo prekliatím nikdy nezomriet' [...] aký je v tom problém, ak to, čo sa zrodilo, tiež hynie? A to, čím hynie, je alebo meč, alebo mučidlo, alebo more, alebo tehla zo strechy, alebo tyran. Čo ti na tom záleží, ktorou cestou zostúpiš k Hádovmu príbytku.“ Diss. II, 6, s. 138-9, „,[...] tiež iní sa musia narodit', rovnako ako i ty si sa narodil, a až sa narodia, musia mat' priestor, obydlie a obživu. Ale ak oni prví privší neodídu, čo ostáva tým po nich? Prečo si nenásytný? Prečo nepoznáš mieru? Prečo chceš tiesnit' vesmír?“ Diss. IV , 1, s. 301 a „Smrt' nie je zlo, lebo nie je nič, čo by bolo nečestné.“ Diss. I, 24, s. 105. 
konštruktívne emócie kl’udu a vyrovnanosti. Epiktétos píše: „Ludia nie sú znepokojení vecami, ale svojimi vlastnými názormi o veciach. [...] Kedykol'vek teda narážame na prekážky alebo sa znepokojujeme, alebo sa rmútime, nikdy neobviňujme iného, ale seba sami, to jest svoje vlastné názory. “i Ostatná myšlienka o vplyve myslenia na podobu nášho emocionálneho stavu, vnútorného naladenia a vzt'ahu ku svetu našla svoj moderný korelát v psychoterapiách označovaných ako kognitívne.ii Albert Ellis $^{*}$ ako kognitívny terapeut kladie medzi vonkajší podnet A a emočne nabitý dôsledok $\mathrm{C}$ ešte systém názorov, postojov a presvedčení $\mathrm{B}$, ktoré práve ovplyvňujú podobu $\mathrm{C}$, takže $\mathrm{C}$ nie je bezprostredne spôsobené $\mathrm{A}$. Ellis preberá Epiktétovu rétoriku, ked' hovorí, že v našej moci nie je napr. to, akému druhu prijímacieho pohovoru do zamestnania budeme podrobení, kto bude pohovor viest',... čo ale v našej moci máme, je spôsob, ako sa $\mathrm{k}$ pohovoru, reakcii na zisk alebo nenadobudnutie práce, postavíme. My sme pánmi našich B-názorov, my a len my rozhodujeme o tom, čo pre nás neúspech $\mathrm{v}$ pohovore bude znamenat'iii Základom psychopatológie tak

\footnotetext{
${ }^{\mathrm{i}}$ Ench. 5, s. 29.

V rovnakom duchu tiež „Maj na pamäti, že t’a urazí nie ten, kto ti nadáva alebo t’a bije, ale tvoja mienka, že t’a títo l'udia urážajú. Kedykol'vek t’a teda niekto rozčúli, vedz, že t'a rozčúlila len tvoja domnienka.“ Ench. 20, s. 33, vid’ tiež: „Ench. 1, s. 27-8, Diss. I, 9, s. 76 a Ench. 16, s. 32.

ii Kratochvíl 2002, s. 69.

* Albert Ellis (1913-2007): autor psychoterapeutickej koncepcie REBT - racionálne emočná behaviorálna terapia

iii Predpokladajme napr. situáciu, že u pohovoru, v ktorom sa uchádzame o pracovné miesto, neuspejeme. Na situáciu môžeme reagovat' napr. bud': „No, urobil som, čo sa dalo, ale bohužial mali uchádzačov s lepšou kvalifikáciou. Škoda, ale určite to nie je jediné zamestnanie na svete. Tak čo keby som sa z tej skúsenosti poučil a pokúsil sa o získanie niekol'kých iných, podobných miest.“ alebo „Rozhodne som si mal u toho rozhovoru počínat' lepšie. Urobil som niekol'ko chýb, ktoré som urobit' nemal. To zamestnanie bolo pre mňa ako stvorené a je príšerné, že som ho nezískal. Počínal som si tak hrozne zle, že pravdepodobne zlyhám aj pri d'alšom pohovore aj u iných zamestnaní. Ako som mohol byt' tak hlúpy! Musím zohnat’ podobné miesto, ako bolo toto, inak môj život nemá cenu. [...] To
} 
u Ellisa (a rovnako Epiktéta) ako kognitívneho terapeuta nie je nič iné ako iracionálne myslenie. ${ }^{\mathrm{i}}$

\section{Námietky voči účinnosti kognitívnej terapie:}

O možnostiach kognitívnej terapie sa vedú polemiky. Podl'a niektorých psychoterapeutov je v praxi naprosto neplodné, ked’ sa napr. $\mathrm{k}$ neurotickému pacientovi či fóbikovi približujeme s rozumovými argumentmi.ii Námietku voči takémuto typu terapie výstižne charakterizuje Kratochvíl, ked’ konštatuje: „Klinický pracovník [...] sa však t’ažko zbaví námietky, že nielen myšlienky môžu ovplyvňovat' emócie, ale že tiež emócie ovplyvňujú myslenie a že v mnohých prípadoch môže byt' príčinný

je hrôza! Som to ale chudák.“ Prvý postoj k neúspechu označuje Ellis ako racionálny, druhý ako iracionálny, a teda zdroj deštruktívnych emócií. Ellis 2001, s. 22n.

${ }^{i}$ Kognitívne psychoterapie nerecipujú Epiktéta celého, ale vyberajú si z neho len určitú čast', a to jeho zameranie na myslenie ako determinant psychického stavu. Tento motív navyše zasadzujú do nových súvislostí. $\mathrm{Z}$ toho dôvodu je medzi kognitívnou terapiou a Epiktétovým modelom nemálo odlišností. Ak napr. Epiktétos považuje frustráciu za naprosto deštruktívnu emóciu, Ellis ju vníma pozitívne, ked’ pôsobí ako motivácia pre, poctivé a dôkladné vykonanie pôvodne frustrujúcej udalosti. Ellis 2001, s. 22n.

ii Condrau 1998, s. 213-4.

Ostatným námietkam vehementne čelí jeden z hlavných protagonistov kognitívnej terapie $A$.

T. Beck. Na obhajobu kognitívnej terapie vyberám Beckom uvádzaný prípad pacienta, ktorý trpel fóbiou zo psov. „Pri d’alšom rozhovore pacient oznámil, že od doby nášho posledného stretnutia videl mnoho psov. Popísal niečo, čoho som si až do tej doby nevšimol - že vždy, ked' uvidí psa, napadne ho niečo ako: ,On ma pohryzne!' Ked’ sa zameral na tieto myšlienky, pochopil, prečo je úzkostný: automaticky hodnotil každého psa ako nebezpečného. Uviedol, že mal strach, že bude pohrýzaný, aj ked' sa stretol s malinkým pudlom. Povedal: ,Uvedomil som si, ako je smiešne mysliet' si, že by ma taký malinký pes mohol pohrýzt'. 'Tiež si uvedomil, že ked' sa stretol s väčším psom na vodítku, hned’ začal mysliet' na tie najhoršie možné eventuality. ,Ten pes na mňa skočí a zahryzne sa mi do oka', ,Skočí na mňa zozadu, prehryzne mi krk a zabije ma!' V priebehu troch týždňov bol pacient schopný svoj dlhotrvajúci strach zo psov prekonat', ked' si opakovane uvedomoval, aké myšlienky ho pri stretnutí so psami napádajú.“ Beck 2005, s. 170 a 174. 
vzt'ah opačný, ako kognitívna teória predpokladá.“i Objav dôležitosti emócií pre racionalitu má vo vzt’ahu k Epiktétovmu modelu kognitívnej terapie, v ktorej sú emócie vždy len produktmi kognitívnych procesov, závažné dôsledky. Goleman tvrdí, že po tom, čo sme zistili, že v istom zmysle človek disponuje dvomi mozgami, dvomi druhmi myslenia a dvomi druhmi inteligencie - emočnej a racionálnej -, stratila myšlienka o potláčaní emocionality človeka ako čisto racionálnej bytosti zmysel a mala by byt' nahradená myšlienkou o rovnováhe a harmonickom vzt'ahu emócií a rozumu.ii Podl'a Damasia majú i na „najracionálnejšom“ rozhodovaní podiel emócie. Damasio pozoroval vel'ké množstvo pacientov s porušeným čelným lalokom predného mozgu, aby zistil, že schopnost' týchto l'udí správne sa rozhodovat' bola výrazne oslabená, a to napriek tomu, že nevykazovali znížené IQ, netrpeli žiadnou paralýzou ani žiadnou vadou reči a pod. Životy týchto l'udí sa však rúcali, radostné správy i tragické udalosti prijímali l'ahostajne, bez akejkol’vek známky smútku, l'útosti, či hnevu. Títo l’udia sa transformovali v racionálnych idiotov. Celá vec tak ukazuje na to, že strata emócií je zdrojom iracionálneho chovania. Inak povedané, emócie sú pre racionálne rozhodovanie naprosto nevyhnutné.iii

Povážme d’alej, aké dôsledky má vykorenenie iracionality a kultivácie emocionality z l'udskej prirodzenosti vo vzt'ahu k det'om alebo mentálne postihnutým. Vzhl'adom k tomu, že Epiktétos považuje človeka jedine za rozumovú bytost', diet'a ako disponujúce rozumom len v určitej oslabenej forme alebo vôbec nie, je vylúčené z dôverného vzt'ahu $\mathrm{k}$ rodičovi, pretože takýto vzt'ah nie je vyjadrením rozumového uchopenia

\footnotetext{
i Kratochvíl 2002, s. 74-5.

Ostatné myšlienky iným spôsoobm vyjadril Blaise Pascal: „Le coeur a sa raison que la raison ne connaît pas.“ Citát prebratý v pôvodnom znení z Condrau 1998, s. 203.

ii Goleman 1997, s. 36-38.

iii Goleman 1997, s. 37, 60.
} 
sveta a ako výraz pudovosti, afektovanosti alebo nedokonalého rozumu je vzt'ahom, ktorý nie je hoden človeka ako človeka, pretože ho zráža na úroveň zvierat, ktoré sú schopné vzt’ahovat' sa ku svetu jedine a práve skrze svoju dispozíciu pudovosti. Voči nim sa ale práve človek má na svojej ceste kultivácie vymedzit’. Epiktétos tak ponúka na výber dichotómiu: človek alebo zviera, človek, alebo diet'a.i Matějček avšak podotýka, že emočná náklonnost' diet’at’a $\mathrm{k}$,materskej osobe“, smiech a plač, sú niečím naprosto prirodzeným. Diet’a by podl'a Matějčka malo vediet' prežívat' smútok a strach.ii Tie však Epiktétos považuje za nežiaduce deštruktívne emócie. Vester poukazuje na vel'ký význam prvých mesiacov detstva na intelektový a emocionálny vývoj diet'at'a.iii Vzhl'adom na súčasný stav bádania, podl'a ktorého sa nervové dráhy emočného mozgu formujú predovšetkým pôsobením našich zážitkov v detstve,iv je Epiktétov nezáujem o emocionalitu diet'at'a vskutku postojom, ktorý možno iba odmietnut'. Čo sa týka psychoterapie, z ostatného vyplýva, že pre Epiktéta nepripadá diet’a ako terapeutický pacient do úvahy.

i Epiktétos: „Lebo čo je diet'a? Nevedomost'. Čo je diet'a? Neznalost'““ Diss. II, 1, s. 127.

Rist konštatuje, že medzi stoikmi nepanovala v otázke povahy rozumu diet’ata zhoda. Alebo sa prikláňali $\mathrm{k}$ variante, že rozumom disponuje len čiastočne, alebo vôbec nie. Podl'a druhého názoru vyrastá človek z tvora čisto animálneho, pudového, riadiaceho sa púhym inštinktom a trvá mu sedem alebo až štrnást’ rokov, kým sa u neho vyvinie rozum. K tomu viac v Rist 1998, s. 48-9 a Long 2003, s. 214. Podla Sorabjiho nepovažovali stoici diet'a pre jeho rozumovú nespôsobilost' - za vhodného filozofického pacienta. Rovnako tak nepovažovali za svojich pacientov ani mentálne postihnutých. Sorabji 1999, p. 804. Bonhoffer sa dokonca domnieva, že stoici považovali diet’a pre absenciu jeho rozumových daností za rovné zvieratu. Bonhoffer 2000, s. 205.

ii Matějček 1996, citácia s. 95, ostatné s. 25n a na iných miestach.

iii Vester, 1997.

iv Goleman 1997, s. 37. 


\section{Direktivita a rigidita Epiktétovej terapie:}

Epiktétos ako terapeut pôsobí na pacienta priamym usmerňovaním jeho myslenia, postojov a chovania. Epiktétos nie je - v duchu Sokratových myšlienok - pôrodnou babicou, ktorá by len pomáhala pacientovej svetonázorovej orientácii a liečbe na svet, pretože Epiktétos pacienta direktívne $^{\mathrm{i}}$ orientuje, čím supluje úlohu samotnej rodičky. Ak Sokrates hranicu medzi laikom a expertom stiera, ked’ hlása „Viem, že nič neviem“, Epiktétos razí opačne „Viem, že sa mýliš v tom a tom“. Sokratova maieutika je u Epiktéta odmietnutá a nahradená predstavou o terapeutovi ako znalcovi a držitel'ovi poznania a klientovi ako pasívnom objekte očakávajúcom terapeutovu expertízu. $\mathrm{V}$ rozhovoreii s pacientom kladie terapeut otázky, ktoré vedú k odhaleniu nekonzistentnosti a deštruktívnej povahy pacientom zastávaných názorov. $\mathrm{V}$ dôsledku nadobudnutej vedomosti pacient prehodnocuje svoje životné názory a vzdáva sa tých, ktoré pôvodne považoval za správne. Nikto podl’a Epiktéta nechybuje dobrovol’ne, pravda je človeku prirodzená a prisviedčat' jej opaku znamená páchat' na sebe zločin. Preto, pokial' terapeut vyvedie pacienta zo zajatia

\footnotetext{
i „Prečo sa teda hneváme? Pretože si ceníme predmetov, o ktoré nás títo l'udia pripravujú. Nuž, neceň si svojich šiat a nebudeš sa hnevat' na zlodeja; neceň si krásy svojej ženy a nebudeš sa hnevat' na cudzoložníka. Vedz, že nie je zlodeja a cudzoložníka vo veciach, ktoré sú tvoje, ale len v tých, ktoré sú cudzie a nie sú vo tvojej moci. Ak sa zriekneš týchto vecí a ak ich budeš pokladat' za nič, na koho sa ešte budeš hnevat'? Ale pokial' si tieto veci ceníš, hnevaj sa skôr na seba ako na tamtých l’udí.“ Diss. I, 18, s. 94-95.

ii Hadot považuje vôbec za typický prvok helenistickej filozofie, že sa realizuje $\mathrm{v}$ rozhovore; dialóg je tu priestorom, na ktorom filozof ponúka partnerovi transformáciu spôsobu jeho života. Stoická filozofia v obecných rysoch, a Epiktétos v jej rámci, nie je teoretizovaním osamelého filozofa, pretože sa realizuje ako životná prax, ktorá sa predáva prostredníctvom dialógu vo vzt’ahu k druhému či druhým. Hadot 1995, s. 264-275.
} 
mýlky, ten sa rád prikloní $\mathrm{k}$ jej opaku, na stranu toho, čo mu je vlastné a prirodzené, na stranu pravdy.i

Vylíčený prístup k pacientovi je často predmetom kritiky, ked’ sa mu vytýka nahradenie záujmu o človeka samotného záujmom o jeho chorobu, ktorá sa tak ocitá v centre terapeutovej práce. V dôsledku toho sa pacient mení na záhadu, problém, ktorému je treba príst' na kíb, takže sa redukuje na púhy „objekt“. Terapia tak nadobúda podobu autoopravovne: k pacientovi, pokazenej prevodovke, sa pristupuje len na základe štandardizovaného manuálu, $v$ dôsledku čoho sa mení z neopakovatel'ného subjektu na typ, ktorý má vyhoviet' diagnóze pokrývajúcej nekonečné množstvo prípadov. Epiktétova terapia je koncepciou, ktorá, ako sa domnievam, nedokáže na dvoch pacientov s tou istou diagnózou aplikovat' dve rôzne liečby v závislosti na ich neopakovatel'ných osobnostiach. Dalo by sa povedat', že ešte pred tým, než vás Epiktétos ako pacienta spoznal, než ste mu vôbec zaklopali na dvere jeho „liečebne“, už poznal spôsob liečby, ktorý má univerzálnu platnost’ pre všetkých pacientov. Epiktétos vo svojom pacientovi nenachádza neopakovatel'nú individualitu, ale len typ určitej deštruktívnej emócie, ktorá podlieha rigidne stanovenému terapeutickému postupu. Naproti tomu napr. I. Yalom píše, že „Terapeut musí usilovat' o to, aby pre každého pacienta vytváral novú terapiu."ii Humanistická a existenciálna terapia dokonca považujú domnienku o človeku ako súčasti nejakého vyššieho celku za jeho degradáciu. Podobne $M$. Buber a $C$. Rogers odmietajú redukciu človeka na púhy objekt diagnózy a v snahe o zachytenie klienta $v$ jeho jedinečnosti a neopakovatel'nosti akcentujú tzv. liečbu stretnutím, v ktorej terapeut vystupuje z prísnej metodologickej objektifikácie a profesionálnej nadradenosti experta do elementárnej situácie $\mathrm{k}$ druhému ako $T y$.

i Diss. I, 18, s. 94. Vid' tiež Diss. I, 26, s. 110 a Diss. I, 27, s. 114.

ii Yalom 2003, s. 47 a Kratochvíl 2002, s. 90n. 
V dialogickom vzt’ahu terapeuta a klienta sa všetky terapeutické metódy ocitajú v služobnom pomere ku klientovej jedinečnosti. Jadro terapeutickej práce potom spočíva v presahu „za“; „Za“ osvojené metódy a terapeutickú teóriu do oblasti, kde dochádza $\mathrm{k}$ stretnutiu terapeuta s človekom $\mathrm{v}$ jeho celostnosti, jedinečnosti a neredukovatel'nosti. ${ }^{\mathrm{i}}$

Epiktétov vzt’ah ku klientovmu duševnému problému má podobu kontrolovanej empatie. Na jednej strane terapeut síce usiluje o to porozumiet' pacientovej situácii, utešuje ho, usiluje o empatický vhl'ad, zároveň ale kontroluje svoju mysel' pred vpádom predstavy, že pacientova situácia je objektívne zlá. Navyše, každý pacientov povzdych, ktorý vždy identifikuje ako výraz deštruktívnej emócie, Epiktétos direktívne koriguje.ii Epiktétova empatia má výrazné medze a podlieha značnej autokontrole. Naproti tomu napr. Carl Rogers a iné psychoterapeutické koncepcie radia terapeutovi, aby sa empaticky vcitoval do klientovej

\footnotetext{
${ }^{\mathrm{i}}$ Rogers 1998 a Buber 1999, s. 18.

Bezprostrednost' terapeutického stretnutia, nezaujatého akoukol'vek metódou, vedie k oceneniu klienta ako subjektu, ktorý nie je devalvovaný na púhy objekt hodnotiaceho popisu. O negatívnych účinkoch objektifikácie klienta nás informuje Rogers prípadom Ellen Westovej, ktorá svoj zážitok z objektifikácia vyjadrila takto: „Analytik mi môže priniest' pochopenie, nie však liečbu.“ Rogers 1998, s. 150.

Epiktétov „chladný“ postoj k pacientovi, ktorý pre neho vystupuje ako púhy objekt očakávajúci jeho direktívne dobrozdanie je prístupom, ktorý nevytvára dostatočné záruky pre vytvorenie dôverného vzt'ahu medzi terapeutom a klientom, vzt'ahom, ktorý samotný, ako vidiet' na príkladoch Rogersa či Bubera, disponuje terapeutickým potenciálom. K tomu viac v Hall 1997, s. 182, Yalom 2003, s. 27, 46, Rogers 1998 a Buber 1999.

ii „Ak niekoho uvidíš ako plače žial'om bud' preto, že mu syn odišiel do cudziny, alebo že stratil svoj majetok, maj sa na pozore, aby t'a pri tom nestrhla predstava ako by bol uvrhnutý do nešt'astia vonkajšími vecami, ale ihned' si uvedom: Tohto človeka netrápi príhoda (pretože nikoho netrápi), ale len jeho názor o nej. Ale nezdráhaj sa aspoň slovami sa mu prispôsobit' a s ním povzdychnút', ak sa naskytne taká príležitost'; len sa maj na pozore, aby si nevzdychal tiež vo svojom vnútri!“ Ench. 16, s. 32, vid’ tiež Diss. III, 2, s. 210.
} 
situácie.i Epiktétos sa tomuto úsiliu vyhýba. Nemôže inak. Keby túto myšlienku akceptoval, prijal by do svojho vnútra i deštruktívne emócie. Ale potom by už nebol terapeutom, lež pacientom.

\section{Záver:}

$\mathrm{Na}$ začiatku Epiktétom navrhovanej terapeutickej cesty, ktorú pacient podstupuje $\mathrm{v}$ reflexii nad vlastným nepokojným, neštastným a chmúrnym životom, stojí výzva ,Poznaj sám seba “ii ${ }^{\text {ii }}$ ved' ,[...] život bez skúmania nestojí ani za to, aby ho človek žil.“iii Človek zistuje, že vo svojej moci má jedine užívanie vlastných predstáv, a to také, že môže byt' $\mathrm{v}$ zhode alebo rozpore $\mathrm{s}$ jeho prirodzenostou rozumovej bytosti. Kultiváciou rozumu sa človek pripodobňuje bohu, objavuje veci z božskej perspektívy, takže je so všetkým, čo sa mu deje, spokojný.

Epiktétos považuje iracionalitu za príčinu každej duševnej choroby. Človek, ktorý usudzuje zle, t.j. v rozpore s rozumovou prirodzenostou sebe vlastnou, prepadá sa do deštruktívnych emocionálnych stavov. V terapeutickom procese sa pacient sústredí na vlastné predstavy a pracuje s nimi ako nástrojmi, ktoré priamo vplývajú na jeho emocionalitu. Pri vedomí rozumovej prirodzenosti človeka a jeho spriaznenosti s bohom vedie vedomá kontrola a regulácia myšlienkových procesov pacienta $\mathrm{k}$ pohl'adu na svet $\mathrm{z}$ božskej perspektívy, ktorý tak nachádza všetky udalosti, ktoré ho stretajú, ako konštruktívne. Ciel'om Epiktétovej terapeutickej snahy je, aby v sebe pacient odhalil boha, začal sa pozerat' na svet jeho očami a dosiahol tak spokojnosti vo svete, v ktorom sa nedeje žiadne príkorie.

i Kratochvíl 2002, s. 56. K povahe vzt'ahu medzi pacientom a terapeutom viac v Hall 1997 , 1997, s. 182 a Yalom 2003, s. 27, 46. K problematike kontrolovanej empatie u Epiktéta viac v Long 2004, s. 253.

ii Diss. I, 18, s. 95.

iii Diss. I, 26, s. 111. 
Z „pohl'adu božieho oka“ je deštruktívna otázka „Prečo práve ja?“ nahradená konštruktívnym stanoviskom typu „Osud to tak chcel“, „Všetko je tak, ako má byt‘،i a pod. Božskou dimenziou kultivovaný pacient sa zbavuje deštruktívnych emócií, aby vo svojom živote našiel klud a mier ako prirodzené stavy duše. Pacient, u ktorého je „liečba bohom“ úspešná, sám žije ako boh na zemi bez ohl'adu na okolnosti, v ktorých sa nachádza. Možno len konštatovat', že Epiktétos je doktorom duše, ktorý injekčnou striekačkou rozumu ordinuje boha. ${ }^{\text {ii }}$

Pacient, oslobodený od deštruktívnych emócií a naladený tak, že je spokojný so všetkým, čo sa deje, zistuje, že ako spoločenský tvor nemôže dosiahnut' konečného liečebného úspechu bez toho, že by nemanifestoval výsledky terapeutického cvičenia vo svojom jednaní vo vzt’ahu k rodine, štátu, bohu, obecne k druhému. Epiktétov človek žije jedine ako súčast' vyššej jednotky, tak ako noha je funkčná jedine ako súčast' človeka. Jedinec, vyčlenený zo širšej perspektívy vzt'ahov zachovávaných k rodine, spoločnosti a bohu, je rovnako neživotný ako amputovaná noha.iii Epiktétov mudrc (vyliečený pacient) nielen „vie“, ale nadobudnuté poznatky aj v každodennom živote manifestuje.

Ako kognitívny terapeut nás Epiktétos upozorňuje na obrovský potenciál rozumu a schopnost' človeka vedome regulovat' vlastný život požadovaným smerom. V tomto aspekte sa javí ako nesmierne podnetný

\footnotetext{
i ,[...] vždy chcem radšej to, čo sa práve deje. Lebo za lepšie pokladám to, čo chce boh, ako ako to, čo chcem ja. K nemu sa chcem pripojit' ako služobník a sprievodca: jeho chcenie je moje chcenie, jeho žiadost' je moja žiadost', slovom jeho vôl'a je moja vôl'a." Diss. IV, 7, s. 330-2 a ,[...] všetko, čo sa deje v zhode s prírodou, správne sa deje.“ Diss. I, 11, s. 78. ii ,[...] poznaj sám seba, [...] bez boha sa o to nepokúšaj.“ iii „Nevieš, že ako noha, ak sa odlúči, už nebude nohou, tak ani ty, ak sa odlúčiš, už d'alej človekom? Lebo, čo je človek? Čast' štátu; najprv toho štátu, ktorý sa skladá z bohov a l'udí a potom toho, o ktorom sa hovorí, že tamtomu je vel'mi blízko, štátu, ktorý je akousi nepatrnou napodobeninou oného vesmírneho.“ Diss. II, 5, s. 136.
} 
a inšpiratívny myslitel’, mimoriadne však podceňuje emocionalitu človeka, čo má fatálne dôsledky. O emócie nejaví Epiktétos žiaden záujem, nemôže teda usilovat' ani o ich samostatnú kultiváciu. Konštruktívne emócie sú vždy len akýmsi výsledkom, vedl'ajším produktom správneho myslenia. Naopak Goleman, Damasio, Rogers ako autori, ktorých som postavil do opozície k Epiktétovi, nabádajú k rozvoju emocionality človeka, a to od raného detstva. Z úlohy, ktorú udel'ujú emocionalite človeka, sa odvíja aj iná podoba terapeutického procesu, v ktorom je direktívnost' potlačená alebo absentuje. Epiktétos naopak - pomocou direktívnej inštruktáže atakuje nevyhovujúce či neuvedomované myšlienkové postupy pacienta a nahrádza ich tými, ktoré identifikuje ako nositele emócií konštruktívnych.

Epiktétova myšlienka o neexistencii utrpenia vo svete (pod zorným uhlom „božieho oka“ je všetko ozdobou, perlou človeku) je hlboko zakorenená $\mathrm{v}$ jeho filozofii prírody. Epiktétos svet (prírodu) kriticky neskúma a spriaznenost' boha a človeka a výskyt boha v tomto svete len konštatuje. V dôsledku toho sa jeho tvrdenia o neexistencii zla vo svete menia na dogmatický článok viery. Účinnost' Epiktétových úvah to značne znižuje. Predstavme si napr. pacienta $\mathrm{v}$ terminálnom štádiu rakoviny, ktorému by poskytoval úl'avu a pomoc dôstojne zomriet' terapeut Epiktétovho razenia. Otázka znie, prečo by mal tento pacient prijat' Epiktéta s jeho filozofiou prírody, ktorá nie je ničím iným ako púhou dogmou, takže je $\mathrm{v}$ spore so samotnou požiadavkou - Epiktétom nárokovaného - rozumového prístupu ku svetu, ktorý každý dogmatizmus vylučuje. V krajnom prípade sa ponúka až bolestivý poznatok, že Epiktétos si berie prírodu/boha za rukojemníka legitimujúceho túžbu po dosiahnutí vnútorného kl'udu a pokoja, čo je nárok, ktorému sa povaha prírody musí 
podriadit ${ }^{i}$ Sčítaný pacient by preto zrejme utíkol Epiktéta Voltairovým Candidom,ii ktorý je brilantným výsmechom neexistencie utrpenia vo svete.

Tým, že Epiktétos všetky vonkajšie veci označuje za indiferentné, len za akési prostriedky na osvedčenie nami kultivovaného rozumu, zbavuje nás možnosti vynášat' o nich hodnotové súdy: nikomu sa nedeje žiadne príkorie („Nežiadaj, aby sa veci diali ako chceš, ale žiadaj, aby sa veci diali ako sa dejú, a bude sa ti v živote vodit’ dobre!“ Ench. 8, s. 30), všetko je tak, ako má byt', takže jediné, čo ako kultivovaná bytost' môžeme vykonat', je nahliadnut túto danost', tento ideálny stav a uviest' našu mysel' do súladu s ním. iii Avšak predstava, že napr. zdravý človek a paraplegik disponujú rovnakou možnost'ou sebarealizácie a prostriedkami na sledovanie vlastného štastia sa javí ako t’ažko obhájitel'ná; je však plne v súlade so zásadami Epiktétovho uvažovania, v ktorom človek vystupuje ako bytost', ktorá má vo svojej moci jedine činnosti, pri ktorých užíva vlastnú rozumovú schopnost'. Epiktétos delí veci jedine na tie, ktoré máme vo svojej moci a tie, ktoré nemáme a pretože žiadnu d’alšiu diferenciáciu nevykonáva, spadajú vražda i prirodzená smrt', všetky typy chorôb od angíny po paraplégiu, atd. do jednej a tej istej priehradky nami neovplyvnitel'ných vecí. Epiktétovo delenie (1. racionálne X iracionálne a 2. to, čo máme $v$ našej moci $X$ to, čo v našej moci nie je) sa tak javí ako nedostatočné.

\footnotetext{
i „Veru, aj keby bol klamný poznatok, že z vecí vonkajších a nezávislých na našej slobodnej slobodnej vôli žiadna sa nás netýka, ja aspoň by som chcel prisvedčit' tomuto klamu, ktorým by som dosiahol št’astia a nerušeného kl’udu v živote; [...]“ Diss. I, 4, s. 63.

ii Voltaire 2009.

iii „V čom spočíva dobro? ,Vo vôli. ‘ V čom zlo? ,Vo vôli.' A v čom to, čo nie je, ani dobro, ani zlo? ,Vo veciach, ktoré nie sú v moci našej vôle. “ Diss. II, 16, s. 163.

„A čo budete prisahat? Že za žiadnych okolností nebudete neposlušní, že si nebudete ani st'ažovat', ani reptat' na niečo $\mathrm{z}$ toho, čo vám bolo od boha dané a že nebudete neradi činit' alebo znášat', čo je nevyhnutné.“ Diss. I, 14, s. 88.
} 
Vonkajšie veci, ktoré žiaden človek nemá vo svojej moci, sú len materiálom, na ktorom uplatňujeme a osvedčujeme našu kultivovanú mysel'. Človeka tak nemožno činit' zodpovedného napr. za druh ním vykonávaného povolania, za čo ale vskutku zodpovedný je, je spôsob, akým k nemu pristupuje. ${ }^{i}$ Nie ide však len o povolania, ale vôbec o akúkol’vek aktivitu - zápasit' na Olympijských hrách, jest', chodit', nadväzovat' priatel'stvá, pracovat',... možno ako filozof, kultivovane a cnostne. Epiktétos sa tu jasne vyrovnáva s predstavou o filozofii ako náuke pestovanej profesionálnymi filozofmi pre profesionálnych filozofov.“ Filozofia ako náuka s terapeutickým potenciálom tu opúšt’a múry filozofických škôl a mieri na ulicu za druhým človekom. Epiktétos má ambíciu pestovat' filozofiu ako spôsob života, pretože vyzýva človeka na jej aplikáciu do každodenných situácií, ktoré ho stretajú. Epiktétos tak pod filozofmi nerozumie nejakú zvláštnu kastu l’udí, ktorí sa pre vznešenost' svojej intelektuálnej činnosti nevenujú takým obyčajným povolaniam ako je sochár, úradník,... aby v tieni filozofickej školy dumali o povahe cnostného života. Kto správne rozumie svojmu rozumovému založeniu a spriaznenosti s bohom, ktoré z toho vyplýva, aplikuje poznatky takto vydobyté na l'ubovol'né množstvo situácií, s ktorými je konfrontovaný, aby tak dosahoval pokoj a kl’ud duše. Filozofia je v Epiktétovom prípade metódou duševnej kultivácie, ktorá prináša duševnú vyrovnanost', čo vylučuje prítomnost' deštruktívnych emócií strachu, úzkosti, nespokojnosti, závisti a iných. Epiktétova filozofia je návodom na dosiahnutie blaženého života prekypujúceho konštruktívnymi emóciami,

\footnotetext{
i „Maj na pamäti, že si hercom takej drámy, akú určí básnik: krátkej, ak chce krátkej, dlhej, ak chce dlhej. Ak chce, aby si predstavoval žobráka, nech aj toho riadne hráš; práve tak, ak máš predstavovat' mrzáka alebo hodnostára alebo prostého občana. Lebo tvoja vec je hrat' dobre pridelenú úlohu, ale vybrat' ju náleží inému.“ Ench. 17, s. 32.
} 
a preto svojho druhu terapiou pre tých, ktorí uvažujú zle, aby sa tak pohltení deštruktívnymi emóciami - zbytočne a umelo trápili a sužovali. ${ }^{\mathrm{i}}$

\section{Literatúra a skratky:}

Diss. - Dissertationes (Rozpravy)

Ench. - Enchiridion (Rukojet')

Fr. - Fragmenty (Zlomky z Rozpráv)

Beck, T. A., 2005, Kognitivní terapie a emoční poruchy, Praha.

Bonhoffer, A. F., 2000, The Ethics of the Stoic Epictetus: An English Translation, New York.

Buber, M., 1999, „Healing Through Meeting“, in: Buber, A. J. (ed.): Martin Buber on Psychology and Psychotherapy: Essays, Letters, and Dialogue, s. 17-22.

Condrau, G., 1998, Sigmund Freud a Martin Heidegger: Daseinanalytická teorie neuróz a psychoterapie, Praha.

Damasio, R. A., 2000, Descartesův omyl: Emoce, Rozum a Lidský mozek, Praha.

Ellis, A., 2001, Člověče, neboj se: Jak zvládnout úzkost dřiv, než ovládne nás, Praha.

Epiktétos, 1972, Rukojet': Rozpravy, Praha.

Goleman, D., 1997, Emoční inteligence, Praha.

Hadot, P.,1995, Philosophy as a Way of Life: Spiritual Exercises from Socrates to Foucault. Oxford UK \& Cambridge USA.

Hall, S. C., et. al., 1997, Psychológia osobnosti: Úvod do teórií osobností, Bratislava.

Kratochvíl, S., 2002, Základy psychoterapie, Praha.

Laertios, D., 1964, Životy, názory a výroky proslulých filosofů, Praha.

i „Podstata dobra je určitý druh vôle, podstata zla je rovnako tak určitý druh vôle. Čo teda sú sú vonkajšie veci? Sú to látky pre našu vôl’u [...]“ Diss. I, 29, s. 117 a ,V čom spočíva dobro? ,Vo vôli.' V čom zlo? ,Vo vôli.' A v čom to, čo nie je, ani dobro, ani zlo? ,Vo veciach, ktoré nie sú v moci našej vôle.“" Diss. II, 16, s. 163. 
Long, A. A., 2004, Epictetus: A Stoic and Socratic Guide to Life, Oxford.

Long, A. A., 2003, Hellénistická filosofie: Stoikové, epikurejci, skeptikové, Praha.

Matějček, Z., 1993, Co, kdy a jak ve výchově dětí, Praha.

Rist, M. J., 1998, Stoická filosofie, Praha.

Rogers, C., 1998, Způsob bytí: klíčová témata humanistické psychologie z pohledu jejího zakladatele, Praha.

Sorabji, R., 1999, „Review: Therapy of Desire.“ Philosophy and Phenomenological Research, Vol. 59, No. 3., s. 799-804.

Yalom, D. I., 2003, Chvála psychoterapie: Otevřený dopis nové generaci psychoterapeutu a jejich pacientü, Praha.

Vester, F., 1997, Myslet, učit se ... a zapominat?, Plzeň.

Voltaire, 2009, Candide, Praha.

Zlomky starých stoikov, 1984, Bratislava. 